\title{
放射線リスクのアプローチ 一歴史的経緯から今日の課題まで
}

甲斐倫明

\section{はじめに}

福島第一原子力発電所の事故によって、放射 線の健康影響とその防護のあり方が社会的に大 きな関心となった。放射線は、レントゲンの X 線発見以来、主に医療分野に扮ける利用に伴う 健康影響として注目されてきたが、戦後の核実 験による影響や原子力発電のエネルギー生産手 段としての発展によって産業衛生および公衆衛 生的な視点が強化されてきた歴史がある。本稿 では、放射線防護の基本的な解説は他を参照し てもらい ${ }^{(1)}$ 、放射線防護に採用されているリ スクアプローチに焦点をあてて論じる。

\section{リスク概念とリスク評価}

リスクの定義は分野による違いが認められる が、基本的な概念は確率的な要素をもって損害 を定量化したものである。放射線防護分野では、 国際放射線防護委員会（ICRP）は1950年代に リスク概念を導入し、絶対安全すなわちゼロリ スクを前提にする防護論をとらないアプローチ をとってきた。つまり、被ばくがゼロでない限 りゼロリスクはないとする考え方を採用してき た。このリスクアプローチが誕生した背景には、 当時の科学的な事実と社会的な判断があった。 科学的な事実には、1928年にミュラーによって ショウジョウバエでの遺伝性影響（hereditary effects、継世代影響ともいう）が線量に直線的
に増加することが明らかにされたことがある。 また1940～1950年代には放射線被ばくによっ て原爆被ばく生存者や放射線科医において白血 病が増加することが報告された。しかし、人の データにおいてしきい線量がない、さらには線 量の効果が累積するという科学的な証拠があっ たわけではない。また、現在までにおいても、 数々の研究が行われてきたにもかかわらず、そ のことが科学的に証明されたわけでもない。実 際、遺伝性影響は今日まで人では観察されてい ない。

当時の科学的背景の下で、ICRPは放射線防 護の基礎にリスク概念を利用することにした。 つまり「しきい線量に関する確かな情報がない のなら、感受性の高い人が白血病に罹る可能性 は累積線量に比例すると想定することが最も慎 重な対応であろう」(2) とした。リスクアプロー チを導入したこの社会的な判断は当時の原子力 エネルギー・放射線利用が世界的に拡大してい く動きに対して配慮したものと考えることがで きる。人が計画的な事業を進めていく上ではハ ザードに対する慎重な対応として先進的であっ た。しかし、その反面、「リスク」に対する恐 れや不安をもたらしてきた負の側面ももち、多 くの論争を呼んできたことも事実である。

1977年にはリスクが定量化された。評価の基 礎にあるデー夕は原爆被ばく生存者の疫学調査 である。原爆という特殊な状況ではあるが、瞬 間的な被ばくであったことから、ガンマ線と 
中性子線の物理的な線量評価による検証を通し て、コンピュータによるシミュレーションに よって一人ひとりの被ばく線量が推定され、胎 児・小児から高齢者までの幅広い年齢にわたる 対象者について長期間の健康追跡調査が行われ てきた。原爆被ばく生存者の疫学調査は現在も 継続して実施されている重要な疫学調査であ る。放射線被ばくの疫学調查は多いが、リスク 推定に使えるだけの規模や信頼性をもって置き かわるデータは少ないだけに、依然として放射 線リスク推定の基礎となるデータである。

リスクの定量化は次の新たな課題を生んだ。 線量反応関係は直線なのか、それとも高線量と 低線量で傾きが変わる曲線なのか、線量反応関 係のモデルの論争が米国科学アカデミーの委員 会BEIR-III報告で行われた。その後も、線量反 応関係のモデルの選択は低線量のリスク推定の 中心課題である。

しきい線量がないと仮定するリスクアプロー チに対して、しきい線量の存在を仮定できて も、その線量を一定の精度で推定することが困 難であることが指摘されてきた。ICRPは、し きい線量があるとしてもそれを決めるための情 報が不確かさをもつならば、仮に決めた線量以 下においてはある確率で影響が起こる可能性が あることになり、結局、リスク（影響の可能性） があるという前提と同じことを意味する。この 論理は、低いリスクにおいては科学的な知見が 不確かであることを補い、現在のしきい線量が

\section{PROFILE}

甲斐倫明

(かい みちあき)

日本学術会議連携会員、公立大学法 人大分県立看護科学大学人間科学講 座環境保健学研究室教授

専門 : 放射線防護・リスク学
ないと仮定するリスク概念を正当化する論拠に なっている ${ }^{(3)}$ 。

それでも、しきい線量が存在しないとする生 物的な根拠が確立しているわけではない。とく に、低線量・低線量率におけるリスクを推定す るための線量・線量率効果係数 (DDREF と呼 ばれる）を生物的な根拠を入れていかに推定す るかが国際的に科学的な争点になっている。

\section{リスク評価の科学論争}

健康影響と聞くと、ある個人が有害物質の曝 露を受けたときにある疾患を発症することを想 定する。その疾患が有害物質に特異的であれば 因果関係を容易に議論することが可能である。

しかし、実際にはがんのように疾患が非特異的 で曝露と無関係で発症する場合、因果関係は統 計的な議論を必要とする。さらに、発症の頻度 が $1 \% 、 0.1 \%$ と低下すればする程、その影響の 観察は困難となってくる。なぜなら、曝露して いない集団（コントロール群）と比較するため に、その集団における疾患罹患率の変動と比べ て曝露による疾患の増加率（過剰リスク）が小 
さいと観察ができないからである。観察できな い場合、過剩リスクがゼロと結論することがで きないが、過剩リスクは曝露していない集団の 罹患率に比べて大きいとはいえないということ はできる。

放射線の健康影響として、低線量の健康リ スクとしてのがんリスクに学術的に注目すると き、過剩リスクがゼロでないかどうかを検証す るために、観察する集団を大きくした疫学調査 が注目されている。最近、注目されるのがCT 検査を受けた小児の白血病あるいは脳腫瘍（い ずれも小児のベースライン罹患率の高いがん） との関係に関する疫学調査研究 ${ }^{(4)}$ 、原子力作 業者が就労期間中に受けた長期的な被ばくとが んの過剩リスクとの関係に関する疫学調査研究 の中で米英仏の3力国（INWORKS と呼ばれる） に注目した研究である ${ }^{(5)}$ 。いずれも原爆生存 者の疫学デー夕に比べると低い線量を受けた集 団を対象にしている。前者の小监CTは178,604 人を、後者のINWORKSは 308,297 人（平均追 跡期間が 27 年）を対象にしている。原爆生存 者の 86,611 人（コホート 120,321 人のうち DS02 で線量が評価されている人）に比べるとその規 模が理解できる。

放射線は被ばく線量という個人ごとのリス クを表現するのに適した測定可能な指標がある ため、他の有害物質のリスクを議論するよりも はるかに精度の高い曝露評価の検討を行ってい る。しかし、健康影響は放射線以外の要因が放 射線とがんリスクとの関係に影響を及ぼす。例
えば、明らかになっている要因として喫煙習慣 がある。喫煙習慣は種々のがんのリスク因子と なることがわかっており、低線量の放射線被ば くと関連がなかったとしても、契煙率が放射線 被ばく線量と相関があると、見かけ上、放射線 被ばくによってがんリスクが増加しているよう に見える。このような喫煙習慣による交絡を補 正すると、放射線被ばくとの統計的に有意な関 係が消失することが日本の放射線作業者の疫学 調査でわかっている。高い精度の曝露評価は必 要条件ではあるが、その精度に見合っただけの リスクを分析できるわけではないことはがんの 原因の複雑さからわかる。

\section{リスクアプローチ}

リスクアプローチは、確率的に影響の発生 の可能性を認め、それに向き合った防護を考え ることになる。リスクとベネフィットをバラン スした判断は正当化の原則と呼ばれ、「個人が 受ける放射線被ばくは正味の利益をもたらす こと」すなわち、被ばくを受ける行為のべネ フィットがリスクを上回ることで被ばくは正当 化される。正当化された被ばくを伴う行為は、 正味のベネフィットを最大限にするためにリス クの低減のための原則は最適化と呼ばれる。第 三の原則は線量制限と呼ばれ、確定的影響のし きい線量を超えないこと、さらに、確率的影響 であるがんと遺伝性影響は線量の大きさに比例 したリスクがあることを前提にしているので、 
どこで線量を制限するかは一律に決めることは 難しいが、上限值を決めることでリスクが一定 以上にならないようにしている。

化学物質のリスクアプローチでは、等リスク 制限で生涯で $10^{-5}$ を超えないようなレベルが使 用されている。数ある化学物質からのリスクを 個々に無視できるレベルに抑える考え方がとら れている。この等リスク制限に対して、放射線 のリスク制限はリスクベネフィット原則をもと に、正味のベネフィットを最大限にするために リスクの低減のための最適化の原則を重視する 防護のやり方を採用してきた。等リスク制限を 採用するリスク論は一種の線引きを行う闇值的 なアプローチということもできる。リスクコン トロールの立場から見れば、閾値的なアプロー チは座りがよくリスクが小さいことを説明する だけで済む。しかし、リスクを最小限にコント ロールできないような状況においては適用でき なくなる。事故後の回復状況において、環境に 存在する有害物質のリスクに向きあう場合、等 リスク制限では立ち行かない状況が生じる。

逆に、リスクベネフィット原則と最適化の 原則の適用は、どこでリスクを受け入れるかと いった判断に迫られ、小さいリスクといえども 人のリスク認知に影響を受け、合意を得ること を難しくする。小さいリスクとしてあらかじめ 合意を得た等リスク制限とは決定的に異なる点 である。

すべての基準がそうであるように、放射線 の被ばく線量の基準もそれぞれが一定の役割を
もっている。放射線の線量基準は、リスクベネ フィット原則によってベネフィットがリスクを 上回ると期待されても、一定のレベルを上限值 として制限するための役割をもっている。ここ には安全という考え方も危険という考え方もな い。安全の裕度を高めるために、リスクの低減 のための最適化の原則を重視するのが放射線防 護の考え方である。そこでの安全に関係した議 論は、リスクの容認性（Acceptability）あるい は耐容性（Tolerability）の問題として捉えられ てきた。問題のポイントは、これをどのように 誰が判断するかという点であろう。このように、 放射線防護は、確率的な要素をもって損害を定 量化したリスクという概念の本質的な性質に向 き合ってきた歴史がある。リスク概念は常に収 まりがわるく、論争を招く傾向にあることも確 かである。

医療における放射線・放射性物質の利用はレ ントゲンのX線発見、キュリー夫人のラジウム 発見以来の長い歴史をもっている。医療の利用 は、疾患の診断や治療のベネフィットが大きい こともあり、リスクベネフィット原則を中心に 動いてきた。しかし、近年、放射線診療の著し い拡大と医療施設間の被ばく線量に差が大きい ことが注目され、最適化原則が強調されるだけ でなく、放射線診断ごとに被ばく線量の目安(診 断参考レベルと呼ぶ）を定め、医療施設がこの 目安線量を大きく上回らないような勧告がされ るようになってきた。この考え方はリスク制限 とは違い、放射線診断の質を標準化する役割を 
もっている。

\section{基準值をどのように決めるか}

リスクを一定のレベルまで制御低減して安全 目標と呼ばれるレベルを社会に示すことの意義 が強調される。定常状態においてリスクをどこ まで制限するのか、これを安全目標と呼べば、 放射線防護では計画被ばく状況における線量目 標値ということになろう。線量目標值は最適 化された線量ということになる。しかし、自然 放射線被ばくを受ける現存被ばく状況では、そ の線量目標值は異なってくる。航空乗務員（パ イロット、客室乗務員）は10,000メートル上空 において地上よりも高い宇宙線の被ばくを受 ける。パリからニューヨーク間では $6.8 \mu \mathrm{Sv} / \mathrm{hr}$ の線量率で $60 \mu \mathrm{Sv}$ の被ばくを受ける。年間の 線量が $5 \mathrm{mSv}$ を超える航空乗務員もいる。この 状況において放射線の安全目標をどう設定する べきか。線量を制限するには乗務時間でしかな い。航空乗務員の放射線被ばくによる過㮃なが んリスクの増加があることを疫学的には証明さ れた科学的な知見はないが、放射線防護ではリ スクアプローチによって、年間 $5 \mathrm{mSv}-10 \mathrm{mSv}$ の参考レベルを設定して、航空乗務員のリスク 教育を強調した放射線防護が勧告される。参考 レベルは、あくまでも安全目標值としての性格 ではなく、リスクアプローチに立った管理上の 上限值としての目安である。

自然放射線の代表的な被ばく源であるラド
ン・トロンは、地質環境と家屋の材質構造や密 閉状態によって被ばく線量が大きく異なるこ とが知られている。年間の線量が数十 $\mathrm{mSv} に$ 及ぶ場合もある。ICRPは、ラドンの参考レベ ルを年間 $10 \mathrm{mSv}$ と勧告した。ラドンの参考レ ベルを考えるにあたって、喫煙との関係をどう 扱うかが議論になった。喫煙はラドンよりもリ スクが大きいだけでなく、ラドンと超相乗的に 作用して、喫煙者は非喫煙者よりもラドンのリ スクが高くなる。この事実を前にして、ラドン のリスクをどこに注目して基準值を考えるべき か。公衆衛生上の健康に注目すれば明らかに喫 煙を優先して制限することがリスク低減には効 果的である。しかし、哭煙は個人の選択である ので、ラドンの小さい非喫煙者のリスクを前提 にした放射線防護を選ぶことは難しい。ICRP は喫煙者と非喫煙者の混合集団を前提にしたリ スク評価から参考レベルを選択した。

以上のように、基準值と通常呼ばれるもの はある役割をもった参考レベルであることが多 い。放射線防護ではリスクアプローチを基礎に 置くからこそ、その意味とリスクの拈よその大 きさを伝える必要がある。

\section{おわりに}

安全を「受け入れることのできないリスクが ないこと」と定義する傾向がある。これはリス クを用いた安全の定義ということができよう。 従来、リスクは安全に対する対義語と誤解され 
がちであるが、リスク概念をより予防あるいは 公衆衛生の観点から積極的に採用し発展させる べきであろう。しかし、一方で、prospective な概念であるリスクが、 retrospectiveに利用さ れるとき、たとえ線量が低くても被ばくを受け た人の不安を和らげることの難しさを福島事故 後において経験している。リスク認知の観点か らリスクという受け止め方には否定的な要素が 多い。この社会的なギャップをどのように考え ていくべきかが、これまでの放射線防護のシス テムにつきつけられた課題である。

\section{参考文献}

1. 甲斐倫明(2015), 日本リスク研究学会誌, 25(2), 83-89.

2. ICRP (1959), ICRP Publication 1.

3. ICRP (2005), ICRP Publication 99, Annals of the ICRP, 35(4).

4. Pearce, MS. et al. (2012), Lancet 380 (9840), 499-505.

5. Leuraud K. et al. (2015), Lancet Haematology, 2(7), e276-e281. 